The Cradle of Erewhon

Samuel Butler in New Zealand 


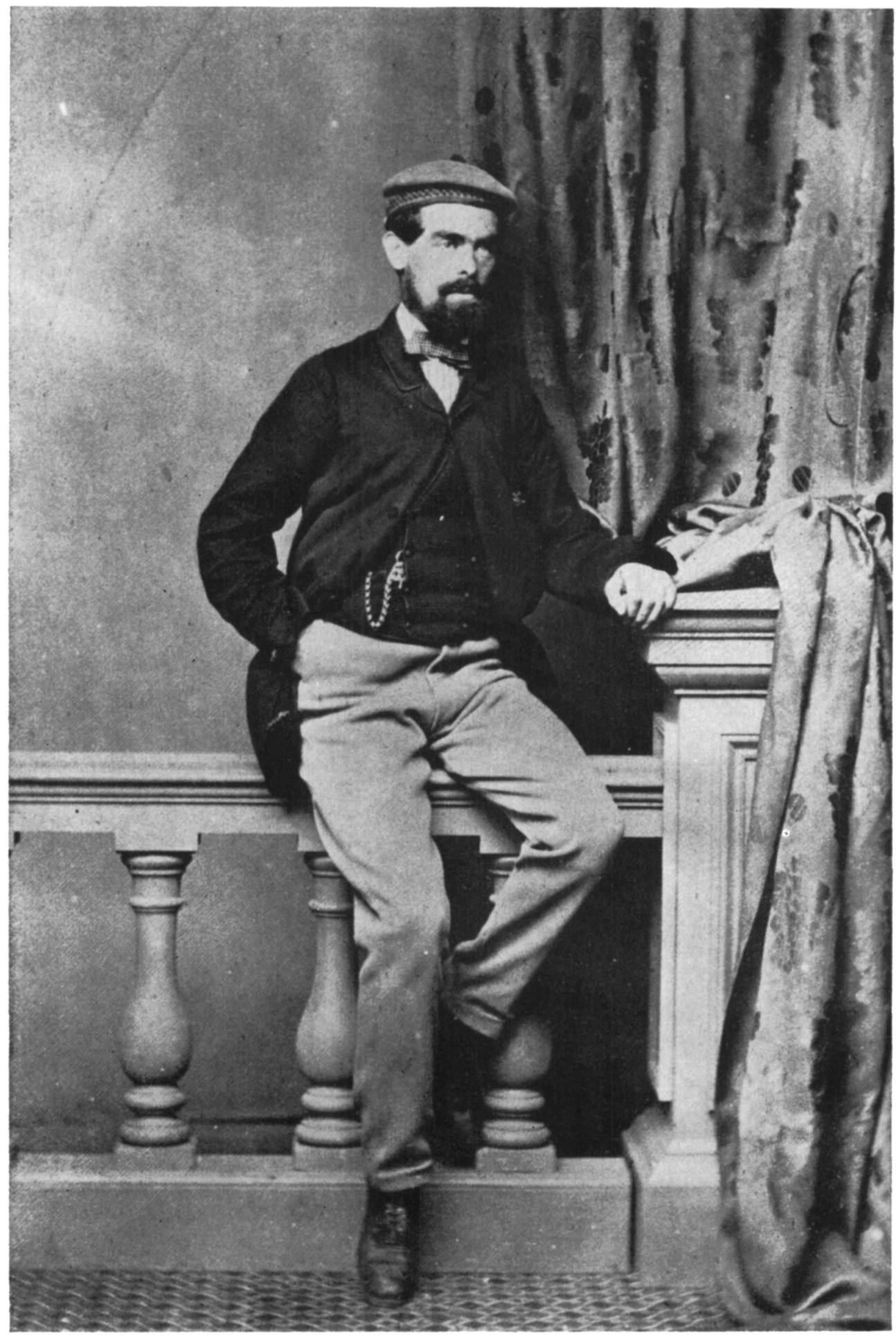

Alexander Turnbull Library

Samuel Butler: Christchurch, 1862 


\section{The Cradle of}

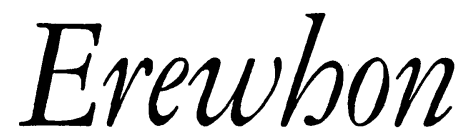

Samuel Butler in New Zealand

By JOSEPH JONES

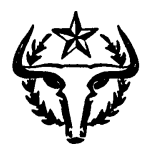

AUSTIN. UNIVERSITY OF TEXAS PRESS 
Copyright (C) 1959 by the University of Texas Press Copyright (c) renewed I987

First paperback printing $20 \mathrm{I} 2$

All rights reserved

Printed in the United States of America

Requests for permission to reproduce material from this work should be sent to:

Permissions

University of Texas Press

P.O. Box 7819

Austin, TX 787 I 3-78I9

http://utpress.utexas.edu/index.php/rp-form

Library of Congress Catalog Number 59-8I 25

ISBN 978-0-292-74I 2 I-8, paperback ISBN 978-I-4773-00I7-6, library e-book

ISBN 978-I-4773-00I 8-3, individual e-book 
TO MANY FRIENDS IN NEW ZEALAND:

Kia ora! 
THIS PAGE INTENTIONALLY LEFT BLANK 